\title{
Life history of the Levant water frog, Pelophylax bedriagae (Amphibia: Anura: Ranidae) in western Iran
}

\author{
Alireza Pesarakloo ${ }^{1 *}$ and Masoumeh Najibzadeh ${ }^{2}$ \\ ${ }^{1}$ Department of Biology, Faculty of Sciences, Arak University, 3815688349 Arak, Iran \\ ${ }^{2}$ Department of Biology, Faculty of Sciences, Lorestan University, 6815144316 Khorramabad, Iran \\ *Corresponding author $\bowtie$ : a.pesarakloo@gmail.com
}

Received: 14 May 2019 Accepted: 10 August 2019 Published online: 30 September 2019

\begin{abstract}
In the present study, we studied the development and morphology of different larval stages of Pelophylax bedriagae (Camerano) at two rearing temperatures $\left(20\right.$ and $\left.24{ }^{\circ} \mathrm{C}\right)$. Eggs were collected from a breeding site in western Iran. Diagnostic morphological characters are provided for Gosner (1960) larval stages 1-46. The larvae hatched about seven days after egg deposition in the laboratory. A principal diagnostic feature, the formation of the funnel-shaped oral disc, became discernible about ten days after hatching at Gosner stage 21 and degenerated at Gosner stage 42. Based on our results, the longest metamorphosis time was observed at $20{ }^{\circ} \mathrm{C}$ whilst the shortest metamorphosis time occurred at $24{ }^{\circ} \mathrm{C}$. The largest body length of larval $P$. bedriagae measured about $54 \mathrm{~mm}$ in 70 days after egg deposition. Compared with the majority of other Palearctic anurans, it appears that embryonic and larval development is usually slow in P. bedriagae.
\end{abstract}

Key words: Development, larval stages, Pelophylax bedriagae, temperatures

\section{Introduction}

Amphibians are unique among the tetrapods in the complexity of their life cycles and the degree to which their life cycles vary in response to environmental conditions (Wells, 2007). The descriptions of anuran embryos and larvae are indispensable to the study of frog taxonomy, phylogeny, life history, and behavior (Gosner, 1960). Globally, amphibians are declining faster than any other vertebrate group (Stuart et al., 2004). Populations of ectothermic animals have a strong dependence on ambient temperature because they do not have an efficient mechanism for physiological thermoregulation (Brattstrom, 1963). Temperature affects amphibian larval developmental rates directly (Hayes and Licht, 1993).

The Family Ranidae is distributed in the whole of Iran except desert areas and has two genera and three species in Iran (Rastegar-Pouyani et al., 2008; Bashiri et al., 2015). The Levant water frog, Pelophylax bedriagae (Camerano), is distributed across the Eastern Mediterranean (Frost, 2011). The species is widespread along the western and south-western parts of Iran (Pesarakloo et al., 2017). Pelophylax bedriagae is threatened by habitat loss as a consequence of wetland drainage, pollution, drought and urbanization of coastal areas (AmphibiaWeb, 2019). 
In this study, first, the external form of the embryonic stages of the Levant water frog, $P$. bedriagae, are described from fertilization to metamorphosis. Then additional comparisons are made here between the developmental larval of $P$. bedriagae and those of other species of Anura with similar larval development. In addition, we present the first staging table for $P$. bedriagae or probably for any Pelophylax species.

\section{Material and Methods}

Two egg clutches of Pelophylax bedriagae were collected from a natural and clean pond in the Khorramabad region of western Iran, at $33^{\circ} 12^{\prime} \mathrm{N}, 48^{\circ} 53{ }^{\prime} \mathrm{E}$ and $2500 \mathrm{~m}$ above sea level (a.s.1.), on 19 April 2017. Clutches were collected by hand and stored in separate polyethylene tubs $(600 \mathrm{~mm} \times 400 \mathrm{~mm} \times 250 \mathrm{~mm})$ filled with water from the natural habitat and transported to the Biology Laboratory, Arak University, Arak, Iran.

The experiment involved two rearing temperatures: 1) $20{ }^{\circ} \mathrm{C}$ and 2) $24{ }^{\circ} \mathrm{C}$ because our observation had shown that, they reflected the average lower and upper estimates of temperatures that $P$. bedriagae tadpoles experience in Khorramabad systems during the period between April and July. Tadpoles hatched from eggs 1 day after collection, and once tadpoles had hatched the egg jelly was removed from the tubs. The experimental conditions provided were based on Pesarakloo et al. (2015). The hatched tadpoles were housed in plastic rearing tanks $(600 \mathrm{~mm} \times 400 \mathrm{~mm} \times 250 \mathrm{~mm})$, and an aquarium water heater $(50 \mathrm{~W})$ was placed in the plastic rearing tanks to set the experimental treatment temperature; each plastic rearing tank had 300 tadpoles and $40 \mathrm{~L}$ water. Experimental samples were kept in a temperature and light-controlled room maintained at $18 \pm 2{ }^{\circ} \mathrm{C}$ ambient temperature and a 12 $\mathrm{h}-12 \mathrm{~h}$ light-dark period.

To ensure that temperatures were maintained at treatment temperatures throughout the entire experimental period, water temperatures were monitored on a weekly basis using a calibrated digital thermometer probe (Pesarakloo et al., 2015). Water volume adjustments were carried out on a weekly basis, and partial water changes $(\sim 30 \%)$ were made once per week. Animals were exposed to a constant feeding regimen throughout the entire experimental period. The food consisted of a mixture of boiled spinach, lettuce and potato (Pesaraklou et al., 2008).

To study the morphological changes on the specimens at various times tadpoles were fixed in $4 \%$ formalin. Upon the appearance of hindlimbs and lung ventilation, we placed a piece of stone inside rearing tanks with apart of the stone out of the water. After completing metamorphosis, the fixed samples were measured with a digital caliper and photographed with a Stereomicroscope equipped with a digital camera. The provided pictures of the development stages of $P$. bedriagae were compared with the development and metamorphosis of Bufo valliceps (Gosner, 1960).

\section{Results}

The number of eggs in two egg clutches varied from 5000 to 6000 , and the embryonic stages include: cleavage, gastrulation, neurulation, elongation and etc. observed in this study. For detailed staging of the following early developmental stages see Table 1.

The larvae hatched about seven days after egg deposition with the yolk reservoir clearly visible. Between 600 and 650 larvae hatched per egg clutches. About five days after hatching, the tadpoles remained clustered in close groups on the bottom. For detailed staging of the following early developmental stages see Table 2 . 
Table 1: Developmental stages of Pelophylax bedriagae, from stage 1-17; stage diagnostic characters according to Gosner (1960).

\begin{tabular}{ccl}
\hline Stage number & Age (days) & \multicolumn{1}{c}{ Diagnostic features } \\
\hline 1 & 1 & Fertilization \\
7 & 1 & 32 cells \\
9 & 1 & Late cleavage \\
10 & 2 & Dorsal lip \\
11 & 2 & Yolk plug \\
12 & 3 & Late gastrula \\
14 & 4 & Neural fold \\
15 & 4 & Elongation, Rotation \\
16 & 4 & Neural tube, Gill plate \\
17 & 5 & Tail bud, Adhesive gland \\
\hline
\end{tabular}

Table 2: Developmental stages of Pelophylax bedriagae, from stage 18-22; stage diagnostic characters according to Gosner (1960).

\begin{tabular}{ccl}
\hline Stage number & Age (days) & \multicolumn{1}{c}{ Diagnostic features } \\
\hline 18 & 10 & $\begin{array}{l}\text { Muscular response to water movement; eye region begins to } \\
\text { develop }\end{array}$ \\
19 & 15 & $\begin{array}{l}\text { Heart beat visible; eye pigmentation distinctly discernible; oral } \\
\text { region begins to stretch upwards; developing dark pigmentation } \\
\text { on body dorsum and tail; yolk reservoir reduced and blood } \\
\text { vessels discernible }\end{array}$ \\
20 & 19 & $\begin{array}{l}\text { Development and circulation of external gills; elongated oral } \\
\text { region; last stage with distinctly visible yolk reservoir; tail } \\
\text { longer than body }\end{array}$ \\
21 & 23 & $\begin{array}{l}\text { Cornea transparent; funnel mouth discernible; dark body and } \\
\text { tail musculature with transparent and distinctly developed fin }\end{array}$ \\
22 & - & Fin circulation begins; dark dorsal pigmentation brightens \\
\hline
\end{tabular}

The funnel mouth became discernible about 10 days after hatching. About three days later, the larvae began to move to the water surface, and after about 20 days post-hatching all tadpoles were feeding. Forty five days after hatching the tadpoles had reached lengths of up to $26 \mathrm{~mm}$. For detailed staging of the following advanced developmental stages see Table 3.

On average around 70 days after hatching, at Gosner stage 27, hindlimbs started to develop. At this time, the largest tadpoles measured about $54 \mathrm{~mm}$. Shortly before metamorphosis the funnel mouth was reduced. About 111 days after egg deposition the first larvae completed metamorphosis. At that time the metamorphosed had total body lengths of 16-19 mm. Reabsorption of the tail took three to five days. While most of tadpoles in the $24{ }^{\circ} \mathrm{C}$ treatment had finished their development and commenced with metamorphosis after 111 days, some individuals in the $20{ }^{\circ} \mathrm{C}$ treatment showed a distinctly slower developmental progress which took up to 140 days, or longer in some cases.

For the developmental Gosner stages 1-17 (see Table 1 and Figs. 1A-D and 2A-D), 18-22 (see Table 2 and Fig. 2E-I), and 27-46 (see Table 3 and Figs. 3A-E, 4 and 5A-D), we assessed diagnostic morphological features and age in days based on 3-4 individuals. The tadpoles in all stages possess a labial tooth row formula of $2(1) 3 /(1)$. This characteristic became discernible about ten days post-hatching (Fig. 2I). 
Table 3: Developmental stages of Pelophylax bedriagae, from stage 27-46; stage diagnostic characters according to Gosner (1960).

\begin{tabular}{|c|c|c|}
\hline Stage number & Age (days) & Diagnostic features \\
\hline 27 & 71 & Hindlimbs bud visible; length of hindlimbs $>0.5 \times$ basal width \\
\hline 28 & 73 & $\begin{array}{l}\text { Length of hindlimbs > basal width; length of hindlimbs }<\text { length of vent } \\
\text { tube }\end{array}$ \\
\hline 29 & 76 & Length of hindlimbs $>1.5 \times$ basal width \\
\hline 30 & 79 & $\begin{array}{l}\text { Length of hindlimbs }=2 \times \text { basal width; length of hindlimbs }=\text { length of } \\
\text { vent tube }\end{array}$ \\
\hline 31 & 81 & Foot paddle-shaped \\
\hline 32 & 83 & Indentation between 4 th and 5 th toe \\
\hline 33 & 85 & Indentation between $3 \mathrm{rd}$ and 4 th toe \\
\hline 34 & 87 & Indentation between 2 nd and $3 \mathrm{rd}$ toe \\
\hline 35 & 89 & Indentation of all toes; hindlimb > vent tube \\
\hline 36 & 90 & Toes 3-5 separated \\
\hline 37 & 93 & All toes separated; pigmentation of hindlimbs darkens \\
\hline 38 & 95 & Metatarsal tubercle visible \\
\hline 39 & 97 & Subarticular patches slightly visible \\
\hline 41 & 99 & Funnel mouth atrophy; vent tube gone \\
\hline 42 & 101 & $\begin{array}{l}\text { Funnel mouth degenerated; forelimbs emerged; spiracle opening } \\
\text { disappeared; Mouth beneath nostril }\end{array}$ \\
\hline 43 & 103 & $\begin{array}{l}\text { Snout pointed; eyeballs starting to protrude; mouth between nostril and } \\
\text { eye }\end{array}$ \\
\hline 44 & 106 & $\begin{array}{l}\text { Terrestrial life modus; tail atrophy; eyeballs further pointed; } \\
\text { longitudinal ridges on back; mouth beneath eye }\end{array}$ \\
\hline 45 & 109 & Tail mostly reduced; mouth posterior to eye \\
\hline 46 & 111 & $\begin{array}{l}\text { Change of pigmentation (cream, fawn); lappet of snout and eyeballs } \\
\text { visible; ridges on back and head become more distinct; tail completely } \\
\text { resorbed }\end{array}$ \\
\hline
\end{tabular}

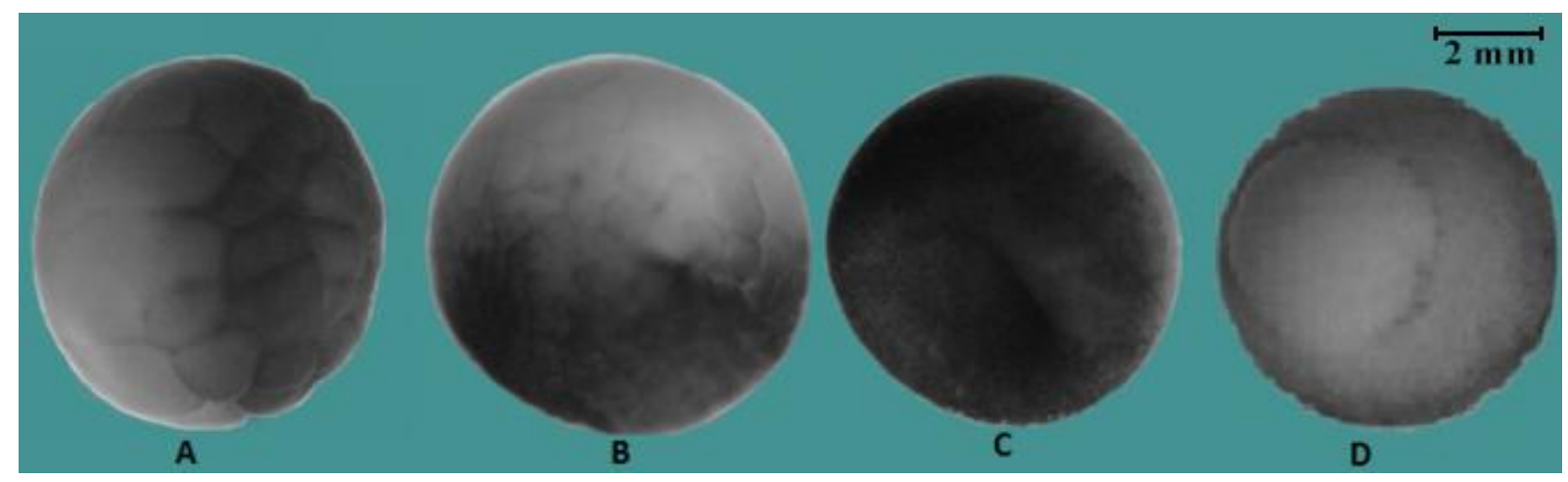

Figure 1: Some stages of embryonic development of Pelophylax bedriagae. (A): stage 7, 32 cells; (B): stage 9, Late cleavage; (C): stage 10, Dorsal lip; (D): stage 11, Yolk plug. 


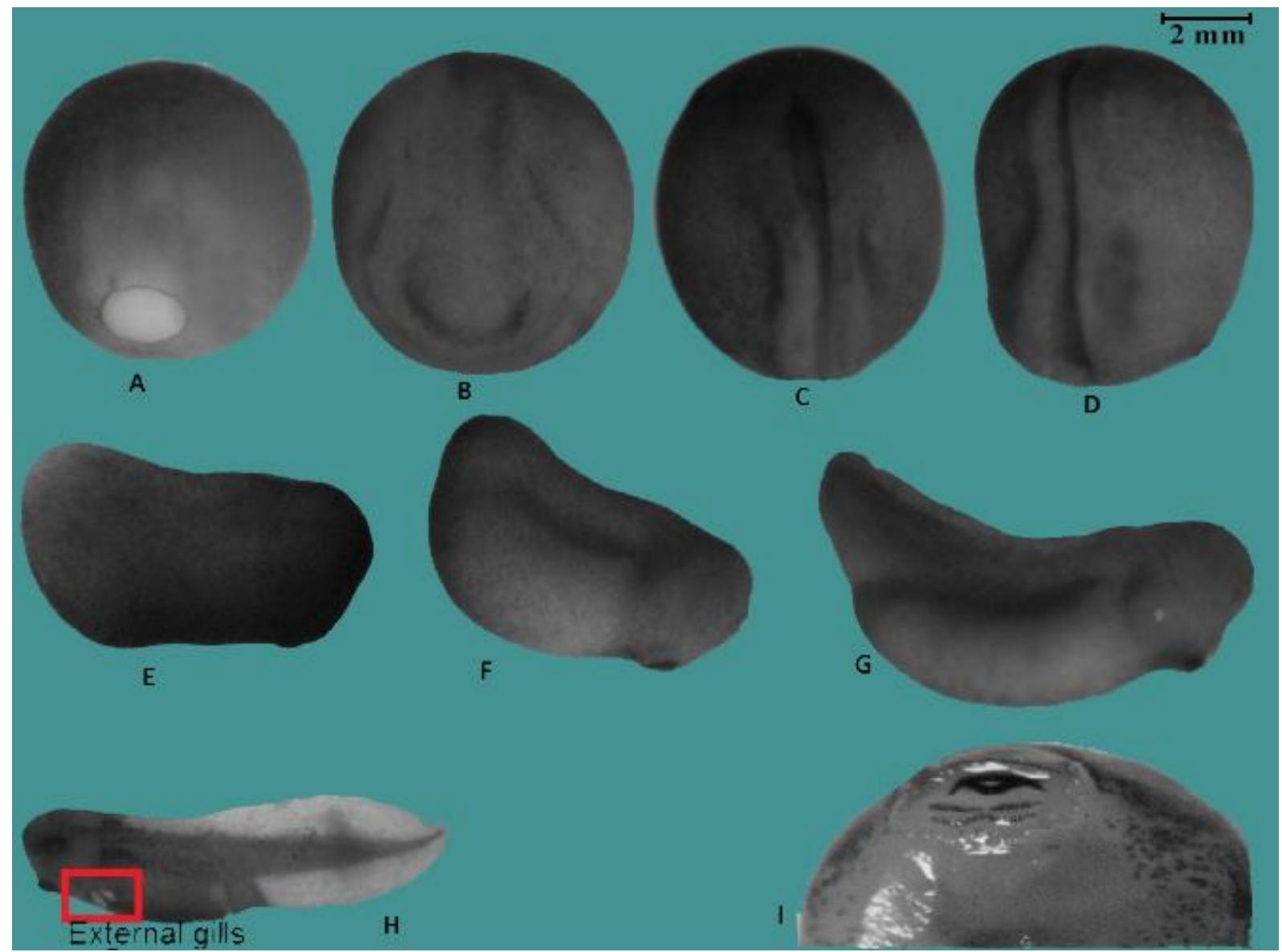

Figure 2: Some stages of embryonic development of Pelophylax bedriagae. (A): stage 12, Late gastrula; (B): stage 14, Neural fold; (C): stage 15, Elongation, Rotation; (D): stage 16, Neural tube, Gill plate; (E): stage 17, Tail bud; (F): stage 18, Muscular response olfactory pits; (G): stage 19, Heartbeat, Gill bud; (H): stage 20, Gill circulation, Tail elongation; (I): stage 21, Labia and Teeth differentiation.
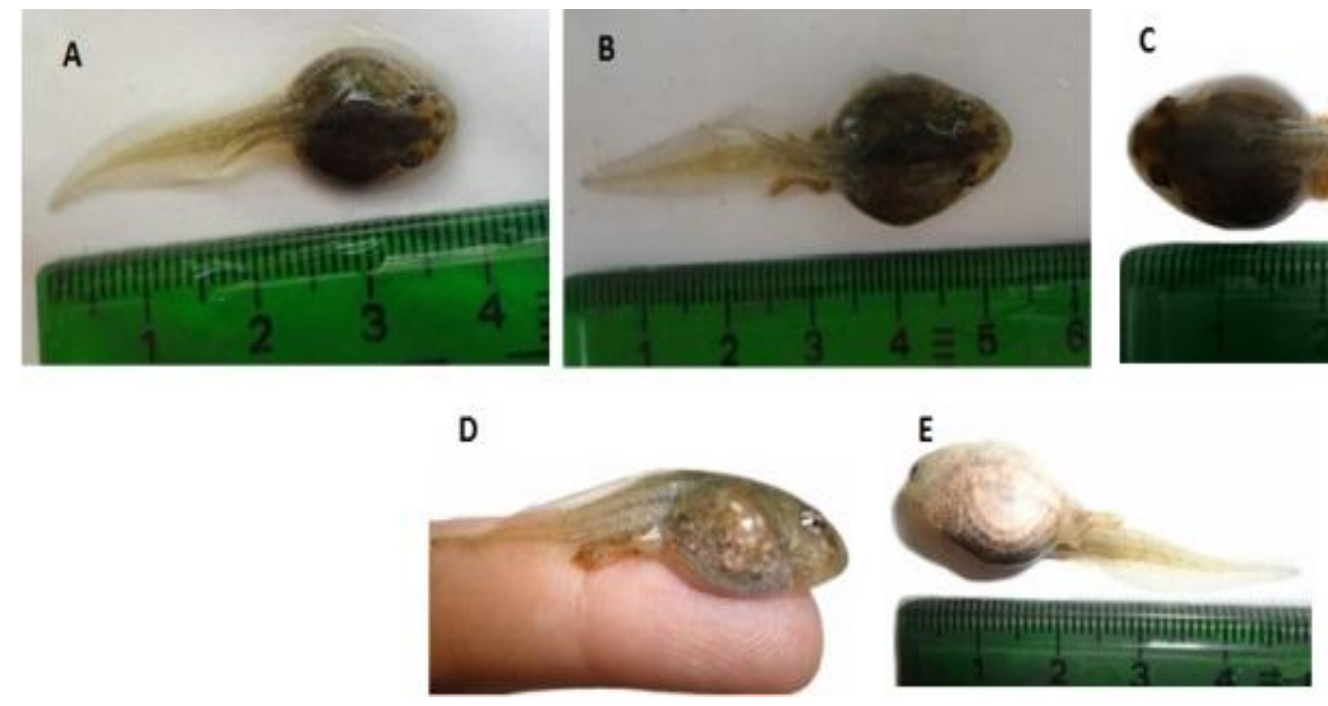

Figure 3: Some stages of larval development of Pelophylax bedriagae. (A-E): stages 27-40, development of hindlimbs bud. 


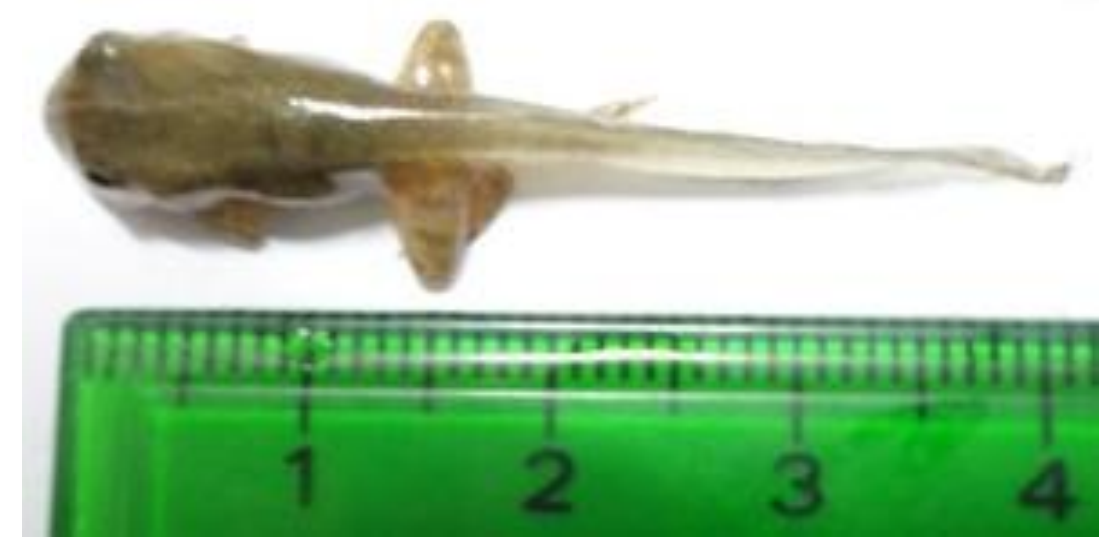

Figure 4: Stage 41 of tadpole metamorphosis in Pelophylax bedriagae as forelimbs are visible.
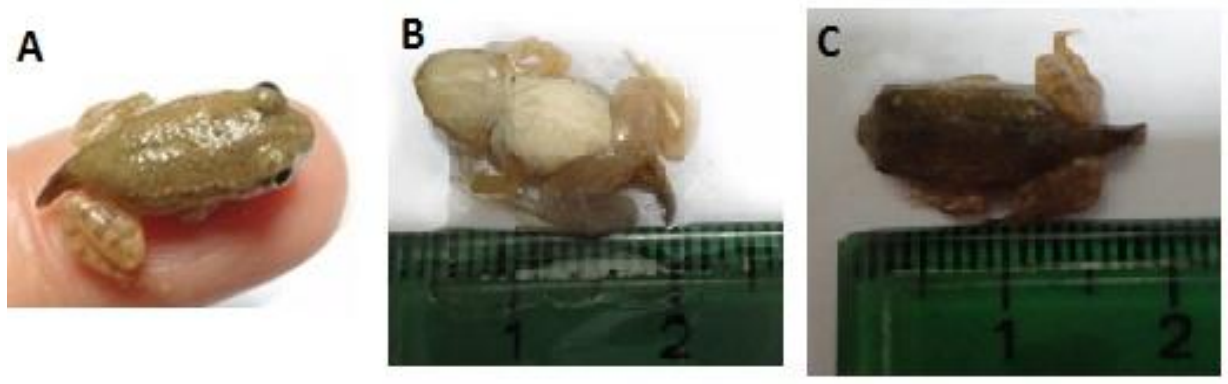

D

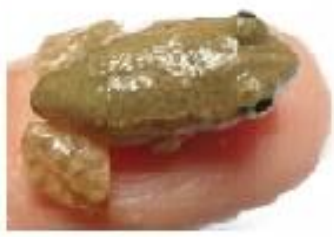

Figure 5: Stages 42-46 of metamorphosis of Pelophylax bedriagae (A-D).

\section{Discussion}

Amphibian behavior is the result of a complex controlling factor for many physiological processes, including temperature and humidity. For example, changes in ambient temperature could disrupt the ability to find food and their foraging efficiency, periods of hibernation and locomotion. Furthermore, the timing of breeding, developmental rate, ovulation and amplexus are associated with the ambient temperature (Donnelly and Crump, 1998; Blaustein et al., 2010).

Pelophylax bedriagae spawns in early-April in the breeding ponds in the Khorramabad region of western Iran. The sympatric amphibian species, namely Bufotes variabilis (Pallas) and Hyla savignyi Audouin are not active during this season. Bufotes variabilis and $H$. savignyi coexist with $P$. bedriagae and they have different breeding times.

The tadpoles of $P$. bedriagae are unique, especially with regards to their oral disc and in all stages possess a labial tooth row formula of 2(1)3/(1). The oral disc became discernible about 17 days after egg deposition at Gosner stage 21 and degenerated at Gosner stage 42. The labial tooth row formula reported in Rana macrocnemis pseudodalmatina (now: Rana pseudodalmatina Eiselt and Schmidtler) in Alang Dareh forest is 3(2)/4(1) (Ebrahimi et al., 2008). Sylvirana nigrovittata (Blyth) and Hylarana erythraea (Schlegel) from Peninsular Malaysia possess a labial tooth row formula of: 2(2)/3(1) and 1/2(1), respectively. Also, Rana banjarana, now in synonymy with Pulchrana banjarana (Leong and Lim), is the only species with a non-emarginate oral disc (Ming, 2005).

From this summary, species of the genus Rana exhibit a wide variation in this character. It seems that, larval length can be regulated by environmental factors, including food 
availability, water temperature and other factors (Blaustein et al., 2010). The largest body length of larval $P$. bedriagae measured about $54 \mathrm{~mm}$ in this study but it measured $78.7 \mathrm{~mm}$ in the Anzali Lagoon, Iran and $125 \mathrm{~mm}$ in the South of France (Mirzajani et al., 2006; Momeni and Zamatkesh, 2005).

The mean number of eggs in a clutch of Pelodytes punctatus (Daudin), the smallest species in the genus Pelodytes Bonaparte is 360 (Toxopeus et al., 1993). It was also reported that the number of eggs spawned by a Pelodytes caucasicus Boulenger female changed with altitude, e.g., fewer eggs near sea level and more eggs in higher environments (Tuniev, 1989). Franzen (1999) reported 58-223 eggs within the clutches of Pelodytes caucasicus. The present study established the number of eggs spawned to be 5000-6000, depending on the female's size, a finding in accordance with the results reported by Chubinishvili et al. (1995).

In Pelodytes punctatus, which was reported to have rather rapid embryonic and larval development, the embryonic development until hatching took 4-14 days, depending on the ambient temperature, and metamorphosis was completed in approximately 70 days (Toxopeus et al., 1993). Also, metamorphosis was completed in 73 days for Rana pseudodalmatina in Golestan Province, Iran (Pesarakloo et al., 2015), 43-90 days for P. ridibundus in Anzali Lagoon, Iran (Mirzajani et al., 2006) and 80-120 days in France (Momeni and Zamatkesh, 2005). Whereas $P$. bedriagae eggs hatched about one week after egg deposition and tadpoles in the $24{ }^{\circ} \mathrm{C}$ treatment had finished their development and commenced metamorphosis after 111 days, some individuals in the $20{ }^{\circ} \mathrm{C}$ treatment showed a distinctly slower developmental progress which took up to 140 days.

Generally, we observed a faster growth at higher water temperatures. We cannot determine if this wide variation also takes place under natural conditions or whether this is due to the artificial environment. Development in a natural habitat may also take longer than in our study. Based on the findings of this study, it can be concluded that the development of $P$. bedriagae is slower compared to other Palearctic anurans. Such advances have the potential to improve the output of amphibian captive breeding programs and may be of value to amphibian conservation. Also, study on the developmental patterns and reproductive strategies of the other species of Pelophylax are highly recommended to find out if there are any similarities and differences between these species.

Studying development is important to help taxonomists assess subspecies and species more completely. We emphasis that the evolution of development is an integrated and integrative field of study, rich in empirical and heuristic value. We present our comparisons of patterns of development among diverse amphibians to help to establish a baseline for further study of species with different evolutionary and developmental histories that result in markedly different phenotypes. We anticipate that such studies will provide a more intensive and betterinformed analysis of pattern and process of the evolution of development.

\section{Acknowledgment}

We would like to thank the honorable authorities of Arak University for helping with the laboratory tasks. We also thank Mehrdad Fathi-Beiranvand, Nabi Ghaedrahmati, Mohsen Amiri and Kamran Farmanpour for help in different parts of this study during field work. We thank the anonymous reviewers for their careful reading of our manuscript and their valuable comments and suggestions. 


\section{References}

AmphibiaWeb. (2019). University of California, Berkeley, CA, USA. www.amphibiaweb.org (Accessed 19 August 2019).

Bashiri, N., Kami, H. G. and Okhli, N. (2015). A preliminary study on the biology of Marsh frog (Pelophylax ridibundus) in Roudbar city, Guilan province. Journal of Animal Environment, 7 (2): 1-11. [in Persian]

Blaustein, A. R., Walls, S. C., Bancroft, B. A., Lawler, J. J., Searle, C. L. and Gervasi, S. S. (2010). Direct and indirect effects of climate change on amphibian populations. Diversity, 2 (2): 281-313. https://doi.org/10.3390/d2020281

Brattstrom, B. H. (1963). A preliminary review of the thermal requirements of amphibians. Ecology, 44 (2): 238-255. https://doi.org/10.2307/1932171

Chubinishvili, A. T., Gokhelashvili, R. K. and Tarkhnishvili, D. N. (1995). Population ecology of the Caucasian parsley frog (Pelodytes caucasicus Boulenger) in the Borjomi Canyon. Russian Journal of Herpetology, 2 (2): 79-86. http://dx.doi.org/10.30906/10262296-2019-2-\%25s-79-86

Donnelly, M. A. and Crump, M. L. (1998). Potential effects of climate change on two Neotropical amphibian assemblages. Climatic Change, 39 (2-3):541-561. https://doi.org /10.1023/A:1005315821841

Ebrahimi, M., Javanmardi, S., Esmaeili, H. R. and Kami, H. G. (2008). Embryo and larval development of Iranian Near Eastern Brown frogs, Rana macrocnemis pseudodalmatina Eiselt \& Schmidtler, 1971 (Amphibia: Ranidae), in Alang Dareh Forest, north-eastern Iran. Zoology in the Middle East, 43 (1): 75-84. https://doi.org/10.1080/09397140.2008. 10638271

Franzen, M. (1999). Verbreitung und Ökologie von Pelodytes caucasicus Boulenger, 1896 in der Türkei . Salamandra, 35 (1): 1-18.

Frost D. R. (2011). Amphibian Species of the World: an Online Reference. Version 5.5. American Museum of Natural History, New York, USA. www.research.amnh.org (Accessed 30 May 2011).

Gosner, K. L. (1960). A simplified table for staging anuran embryos and larvae with notes on identification. Herpetologica, 16 (3): 183-190.

Hayes, T., Chan, R. and Licht, P. (1993). Interactions of temperature and steroids on larval growth, development, and metamorphosis in a toad (Bufo boreas). Journal of Experimental Zoology, 266 (3): 206-215. https://doi.org/10.1002/jez.1402660306

Ming, L. T. (2005). Larval systematics of the Peninsular Malaysian Ranidae (Amphibia: Anura). Ph.D. Thesis. Department of Biological Sciences, National University of Singapore, Singapore. 203 pp.

Mirzajani, A. R., Kiabi, B. and Bagheri, S. (2006). Study of larval growth and population estimation of Rana ridibunda in Anzali wetland. Iranian Journal of Biology, 19 (2): 191202. [in Persian]

Momeni, M. and Zamatkesh, E. (2005). Study of frog farming probability of the Anzali wetland (Rana ridibunda). The First National Congress of Aquatic and Animal Science, Tehran University, Karaj, 1075-1078.

Pesarakloo, A., Rastegar-Pouyani, E., Rastegar-Pouyani, N., Kami, H., Najibzadeh, M., Khosravani, A. and Oraie, H. (2017). The first taxonomic revaluation of the Iranian water frogs of the genus Pelophylax (Anura: Ranidae) using sequences of the mitochondrial genome. Mitochondrial DNA Part A, 28 (3): 392-398. https://doi.org/10.3109/19401736. 2015.1127362 
Pesarakloo, A., Rastegar-Pouyani, N., Najibzadeh, M., Rastegar-Pouyani, E., Gharzi, A. and Shayestehfar, A. (2015). Interactive effects of temperature and food availability on the Marsh Frog (Pelophylax ridibundus) tadpoles in Western Iran. Asian Journal of Conservation Biology, 4 (2): 130-135.

Pesaraklou, A. R., Gharezi, A. and Gholi Kami, H. (2008). Study of embryonic stages and metamorphosis in the jungle frog (Rana macrocnemis pseudodalmatina) in Golestan province (Minudasht city). Research Journal of University of Isfahan "Science", 35 (6): 209-222. [in Persian]

Rastegar-Pouyani, N., Kami, H. G., Rajabzadeh, M., Shafiei, S. and Anderson, S. C. (2008). Annotated checklist of amphibians and reptiles of Iran. Iranian Journal of Animal Biosystematics, 4 (1): 43-66.

Stuart, S. N., Chanson, J. S., Cox, N. A., Young, B. E., Rodrigues, A. S. L., Fischman, D. L. and Waller, R. W. (2004). Status and trends of amphibian declines and extinctions worldwide. Science, 306 (5702): 1783-1786. https://doi.org/10.1126/science.1103538

Toxopeus, A. G., Ohm, M. and Arntzen, J. W. (1993). Reproductive biology of the parsley frog, Pelodytes punctatus, at the northernmost part of its range. Amphibia-Reptilia, 14 (2): 131-147. https://doi.org/10.1163/156853893X00309

Tuniev, B. S. (1989). Distribution, biology and ecology of Pelodytes caucasicus on West Caucasus, In: Problems of Herpetology. Kiew, pp. 259-260. [in Russian]

Wells, K. D. (2007). The Ecology and Behavior of Amphibians. University of Chicago Press, Chicago, USA. 1400 pp. 